McKinsey

\& Company

Can the gold

industry return

to the golden age?

Digging for a solution to the gold mining reserve crisis 



\section{Can the gold industry return to the golden age?}

Digging for a solution to the gold mining reserve crisis 


\section{Executive summary}

The gold industry finds itself at an inflection point between the recent era of cost out initiatives and balance sheet deleveraging, and an increasing need to focus on growth and the replenishment of depleting gold reserves. However, after a period of impairments, write-downs, and value destruction following the M\&A frenzy of the last gold price boom, shareholders in search of improved returns and greater management accountability are unlikely to support significant M\&A programs, which have been the traditional mainstay of production growth and gold reserve expansion for major gold companies. The future strategic options to drive growth will differ across industry players, but all players will need to consider a mix of organic and inorganic approaches if they want to return to growth in an economic and sustainable way.

Since the turn of the century, the gold industry has experienced a roller-coaster ride, with prices rising from USD 255/oz in 2001 to highs of USD 1,906/oz a decade later, before falling to USD 1,056/oz by December 2015. This reversal of fortune led debt-heavy gold companies, which had engaged in aggressive M\&A programs before the peak, to initiate dramatic cost out programs, resulting in all-in sustaining costs (AISC) declining 20 percent to USD 879/oz between 2012 and 2017, and significant impairments totaling USD 129 billion since 2011. The impact of these initiatives coupled with current higher gold prices has restored the health of large gold companies, evidenced by stronger cash flows, leaner cost structures and deleveraged balance sheets. However, this recovery has come at a cost as gold reserves have declined by approximately 26 percent to $713 \mathrm{MOZ}$, due in part to an approximate 70 percent reduction in exploration expenditure as companies sought to preserve cash. This raises the uncomfortable prospect of a looming reserve crisis.

During the last boom, gold companies sought to bolster reserves by launching acquisitions, with annual acquisitions peaking at USD 38 billion in 2011, while the average price paid per ounce reserve in this peak period was often more than 300 percent higher than deals executed a decade earlier. In recent years, shareholders and activist investors have become increasingly vocal about value destruction resulting from aggressive M\&A strategies and despite transaction multiples being at decade lows - management teams are cautious about resorting to this approach to replenish depleted reserves. This challenge is being exacerbated as greenfield exploration programs have failed to deliver but a handful of significant gold discoveries above $6 \mathrm{MOZ}$ since 2006, and there are also long lead times between discovery and first production. As a result, relying on traditional greenfield strategies alone will likely be insufficient for many companies with aspirations to capture growth in this new era.

The strategic response required will differ by company depending on the current strength of gold reserves and project pipeline, internal exploration and project development capabilities, financial balance sheet strength, and the M\&A execution track record. Whatever approach is taken, management teams will need to pursue a multi focus approach, i.e., driving growth via selective exploration and acquisitions while using new methods and technologies offered by digital and advanced analytics. 


\title{
What goes up must come down
}

\begin{abstract}
A popular investment anecdote relates how Sir Isaac Newton - a proponent behind the British government's move from silver to gold as its monetary standard - suffered significant losses in the South Sea Bubble. In early 1720, Newton cashed out with profits of GBP 20,000, doubling his investment, but as the share price continued to rise, Newton lost his nerve and not only invested once, but twice. He supposedly lost most of his investment in the crash that followed and is claimed to have said "[he could] calculate the motions of the heavenly bodies, but not the madness of people." Thus was born the First Law of Financial Gravity: what goes up must come down, and what goes up the most will come down the hardest - a lesson not lost on the gold industry.
\end{abstract}

The gold industry has been on a roller-coaster ride since prices peaked at USD 1,906/oz in September 2011, and companies have undergone a rapid transition from debt-fueled, acquisition-driven expansion and a "production-at-all-costs" mindset, to a period of aggressive downsizing to reduce bloated cost structures and - for some - to avoid potential insolvency. After five years of restructuring, impairments, and write-downs, the industry is recovering and cash flows and profit margins are improving. Many commentators are increasingly confident that the industry cycle has finally turned and is entering an upswing; however, many companies remain cautious about initiating growth strategies - especially those requiring large $M \& A$ programs - as activist investors continue to berate management teams and boards alike for significant value destruction during the last boom and bust cycle.

Exhibit 1

Gold prices peaked above USD 1,700/oz during the 1980s energy crisis and 2003-11 commodity boom, only to sharply decline thereafter

Gold price, 1970-2017, USD/oz, 2015 real

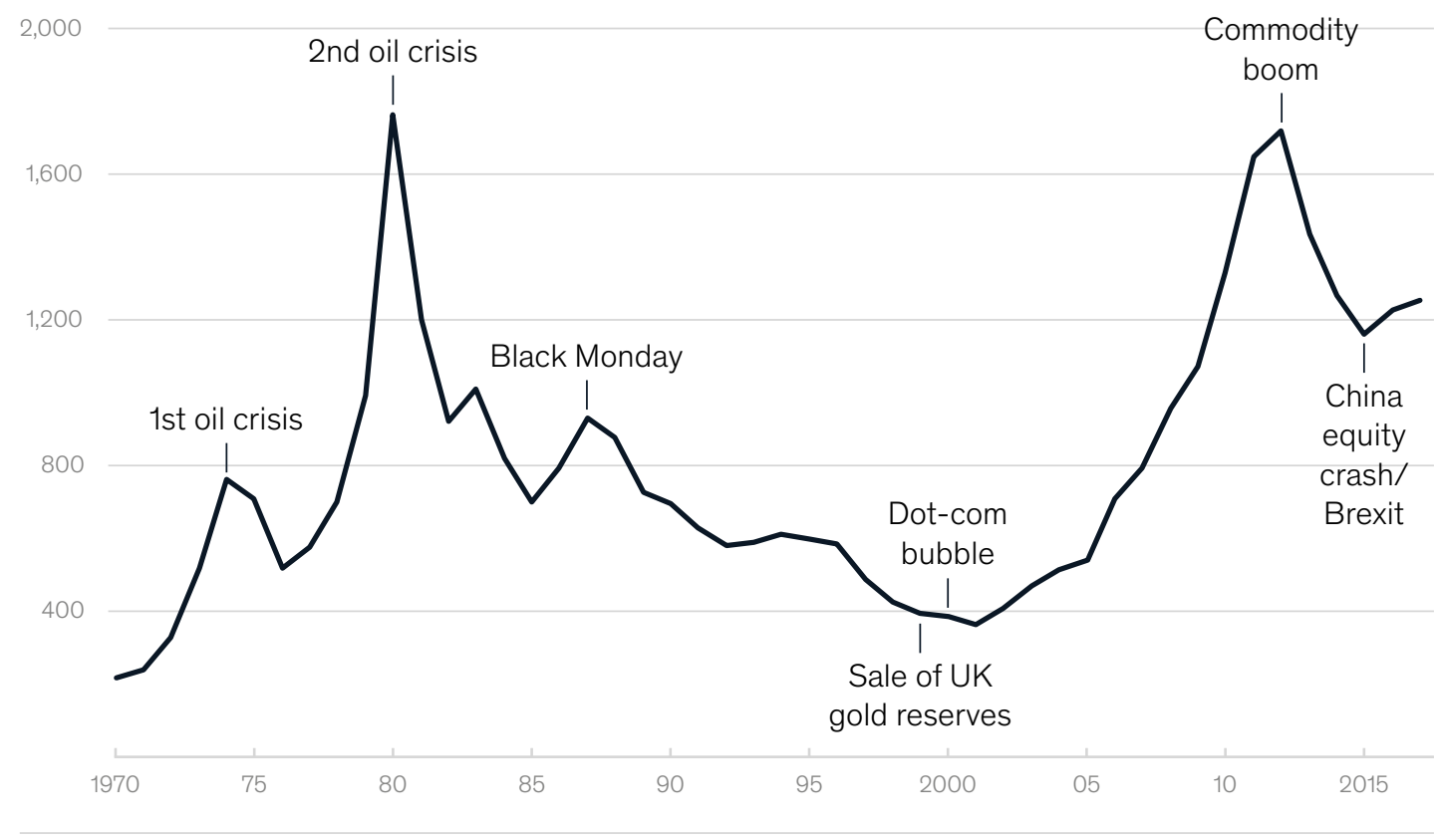




\section{Prices moving ever skyward}

Between March 2000 and October 2002, the NASDAQ Composite lost approximately 80 percent of its value, dropping from 5,047 to 1,114 and, in the process, representing a USD 5 trillion to 7 trillion loss in value. This represented the fallout of the dot-com bubble, which began in the late 1990s and witnessed soaring US equity valuations fueled by speculative investments in internet-based companies. The end of the dot-com bubble and subsequent events were the catalyst for the decade-long rally in gold prices from lows of USD 255/oz in April 2001 to a peak of USD 1,906/oz in September 2011.

The gold price rally in the 2000s. Gold price forecasts follow two schools of thought: one of supply-demand cost-curve fundamentals; the other of macroeconomic factors such as interest rates and exchange rates. McKinsey's assessment suggests that gold price-setting mechanisms reflect a combination of supply-demand and macroeconomics - in particular oil prices, US inflation, US real interest rates, and US dollar exchange rates. Together, these factors enable us to understand the increase in gold prices from 2006 to 2011, during which time stock market returns were close to flat compared to gold price returns of approximately 120 percent. From a fundamentals perspective, this period was characterized by increased demand for gold from emerging markets, with Indian and Chinese jewelry, physical bars, and official coins increasing more than 1,100 tons between 2003 and 2011. At the same time, a number of macroeconomic factors were at play - first, fears of global inflation stimulating gold consumption as a hedge against inflation and economic uncertainty, especially during the 2007 to 2010 global financial crisis; second, increasing concern over debt levels and quantitative easing dampening the investment appeal of US treasury securities and municipal bonds; third, investor belief that China would significantly diversify its foreign currency reserves into precious metals, including gold and silver.

Accelerating M\&A, capital spend, and shareholder value destruction. After two decades of declining gold prices, the rally of the 2000 s provided management teams with an environment in which to focus on growth strategies, in many cases fueled by aggressive acquisitions and poorly managed capital projects. From 2000 to 2010, the industry saw over 1,000 acquisitions with a combined value of USD 121 billion, compared to only USD 27 billion from 1990 to 2000; indeed, at the peak in 2011, in a single year there were over USD 38 billion in acquisitions. Many of these deals were predicated on gold prices continuing to increase, with some industry experts predicting prices to rise above USD 5,000/oz. This drove CEOs to pay premiums of 30 percent and more; for example, in 2009, Goldcorp's USD 229 million acquisition of Canplats was offered at a 41 percent premium to the then share price, while in 2010 Newcrest also offered a 41 percent premium to shareholders in the USD 8.5 billion acquisition of Lihir Gold.

Simultaneously, annual capital expenditure by large gold companies increased tenfold between 2000 and 2012, with aggregate spend exceeding USD 125 billion. Our research shows that two-thirds of projects exceeded budgets by 60 percent compared to initial estimates, and half of capital projects experienced delays between one and three years. Factors leading to cost overruns and delays include rising contractor spend, owner and EPCM cost growth, scope change, industrial retaliation, domestic currency appreciation, and the logistics challenges of remote regions. For example, the South Deep gold mine in South Africa has persistently fallen short of production targets, even after investments starting in 2006 totaling approximately USD 2.5 billion. In 2017, South Deep produced $281 \mathrm{KOZ}$ of gold instead of the expected $315 \mathrm{KOZ}$. In mid-2018, after two labor restructurings at the end of 2017, it was reported that it was unable to quantify the impact of the large-scale restructuring on production in 2019 and later. 
In hindsight, when evaluated against various economic return metrics, many acquisitions and capital projects were misguided. Following the collapse/correction of gold prices in 2012, the industry undertook approximately USD 129 billion of write-downs; indeed, 80 percent of the transaction value of the eight largest mining deals between 2001 and 2011 were impaired (over USD 36 billion was spent on these transactions, which still have negative cash flow), while the industry's return on capital between 2010 and 2016 was only 2.6 percent - significantly lower than the cost of capital. As a result, many shareholders have harshly criticized the industry's track record of creating value, with Paulson \& Co. even going so far as to declare that gold mining shareholders were "like sheep being led to slaughter."

Exhibit 2

\section{Large gold companies cumulatively lost USD 129 bn in value after the industry peak in 2011}

Enterprise value waterfall by major gold companies ${ }^{1}, 2011-18^{4}$, USD billions

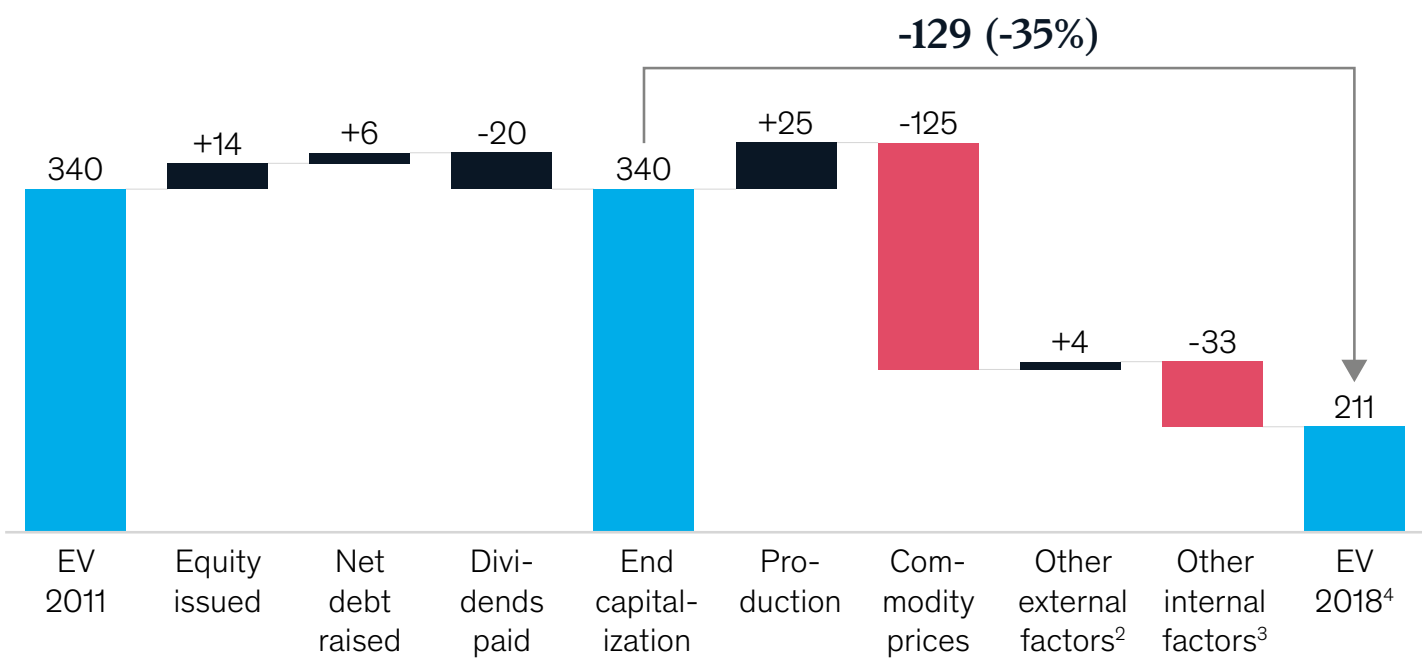

\footnotetext{
1 Barrick, Newmont, AngloGold Ashanti, Goldcorp, Kinross, Newcrest, Gold Fields, PSJC Polyus, Agnico Eagle, Sibanye-Stillwater, Zijin, Harmony, Randgold Resources, Yamana, Freeport-McMoRan, Shandong Gold, Polymetal International, Nord Gold, Zhongjin 2 Exchange rates, factor price inflation, oil prices 


\section{Slamming on the brakes}

After a decade of price escalation, rapid expansion, and acquisition-fueled growth, in 2012 the market finally turned, taking many gold companies by surprise. A fall in gold prices from USD 1,906/oz to USD 1,056/oz between September 2011 and December 2015 put pressure on cash flows and forced companies to move from a "production-at-all-costs" mindset to aggressive cost out programs. While initiatives differed by player, three main strategies were visible.

Driving out costs. The sudden decrease in gold prices ushered in a wave of initiatives to reduce operating costs, which saw weighted average all-in sustaining costs (AISC) fall by approximately 20 percent from USD 1,117/oz to approximately USD 879/oz between 2012 and 2017. Notable cost reduction programs announced during the period included Polyus' 38 percent reduction in AISC from USD 1,002/oz to USD 621/oz through operational improvements, lower sustaining capital spend, and favorable exchange rates; AngloGold's 11 percent reduction in AISC from USD 1,251/oz to USD 1,054/oz through operational improvements, including contract and labor management; and Newmont's 24 percent reduction in AISC by the end of 2015 due to operational improvement and portfolio optimization. These programs were aided by lower oil prices and a stronger US dollar - from 2012 to 2017, Brent Crude Oil was 59 percent lower, while the exchange rates of all key mining countries (China, Canada, Peru, Australia, Indonesia, South Africa, and Russia) depreciated between 10 and 90 percent against the US dollar.

Exhibit 3

Cost out initiatives since 2012 have reduced AISC cash costs by $\sim 21 \%$

All-in sustaining cash costs (AISC) ${ }^{1}$ vs. average gold price, 2012-17, USD/oz

1,670

Gold price, USD/oz

W. Avg AISC, USD/oz
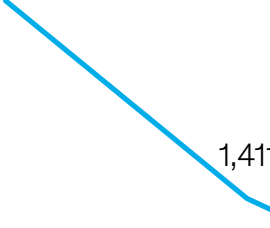

, 411

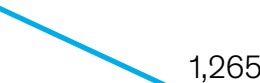

1,249

1,161

1,117

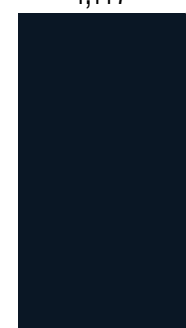

2012

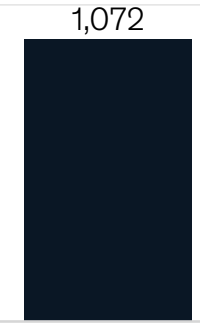

13

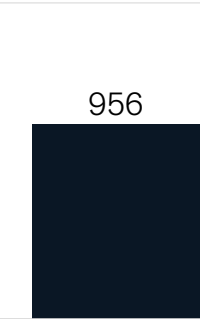

14

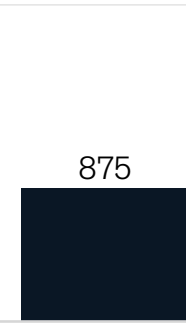

15

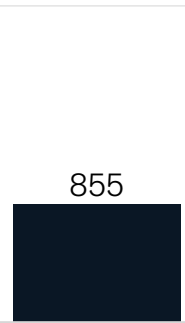

16 
Freezing capital expenditure. Since 2012, all but one of the largest twenty gold companies have significantly reduced capital spend. Struggling to raise debt to invest in new projects, capital expenditure by the largest 20 gold companies fell to approximately USD 12 billion in 2016 from more than USD 30 billion at its peak in 2012. Similarly, exploration budgets were dramatically reduced as companies retrenched both head count and exploration programs: between 2012 and 2016, industry exploration capital fell from USD 20.5 billion to 8.7 billion. For example, Kinross reduced capital expenditure by 50 percent in 2013, with zero growth in capital spend over 2014 and 2015; and Goldcorp reduced growth capital by approximately 40 percent and approximately 60 percent in 2014 and 2015, respectively, as it focused on core assets.

Deleveraging balance sheets. The industry also took dramatic actions to deleverage balance sheets using a combination of asset impairments, divestments, and closures, with industry debt being reduced by more than USD 10 billion between 2013 and 2017. For example, Barrick shed noncore assets to optimize its portfolio and strengthen its balance sheet - in late 2015 it completed the sale of a 50 percent interest in the Zaldivar copper mine in Chile to Antofagasta and divested a 70 percent interest in the Spring Valley project as well as its 100 percent interest in the Ruby Hill mine. Newmont closed or divested projects, including the Midas mine in Nevada, the Jundee mine in Australia, and the La Herradura joint venture in Mexico - all of these divestments were part of the company's policy of focusing on lower-cost, longer-life operations. 


\section{Once bitten, twice shy}

From 2011 to 2015, gold prices fell steeply - despite many global macroeconomic uncertainties - dipping to USD 1,056/oz at the end of 2015 before starting to rise again in 2016 to highs of USD 1,430/oz.

The rising gold price, as well as efforts by the gold industry to lower costs, has strengthened industry cash flows and significantly reduced total debt at gold mining companies. Net debt at 15 of the largest global gold mining companies fell by more than USD 10 billion from its peak in 2014 to less than USD 24 billion in 2017. Leverage ratios have also declined, with net debt to EBITDA falling from 1.6 times to approximately 1.1 times in 2018. As a result, the balance sheets and cost structures of the gold industry are much stronger than five years ago, enabling companies to pay off debt and return cash to shareholders. Growth has reappeared on management agendas and in investor presentations.

However, investors have not forgotten the aftermath of the USD 100 billion deal frenzy between 2005 and 2014 and have punished gold equities accordingly. Since the beginning of 2010, the price of gold has risen by 10 percent, while the GDX, a measure of large cap gold mining companies, has fallen by 60 percent, and the GDXJ, representing junior mining companies, has declined by 74 percent. Along with reflecting the perilous state of the gold industry in 2011, with its bloated and rigid cost structure and over-leveraged balance sheets, this also represents investors realizing the failure of many management teams to execute successful transactions: it is no surprise that in 2017, a mere USD 9 billion of deals were completed, representing a drop of 80 percent from the 2011 peak.

Exhibit 4

Growth in reserves was driven through acquisitions; brownfield and greenfield exploration only offset reserves depleted from production and divestures Reserve waterfall by major gold companies ${ }^{1}, 1998-2011$, million ounces Au

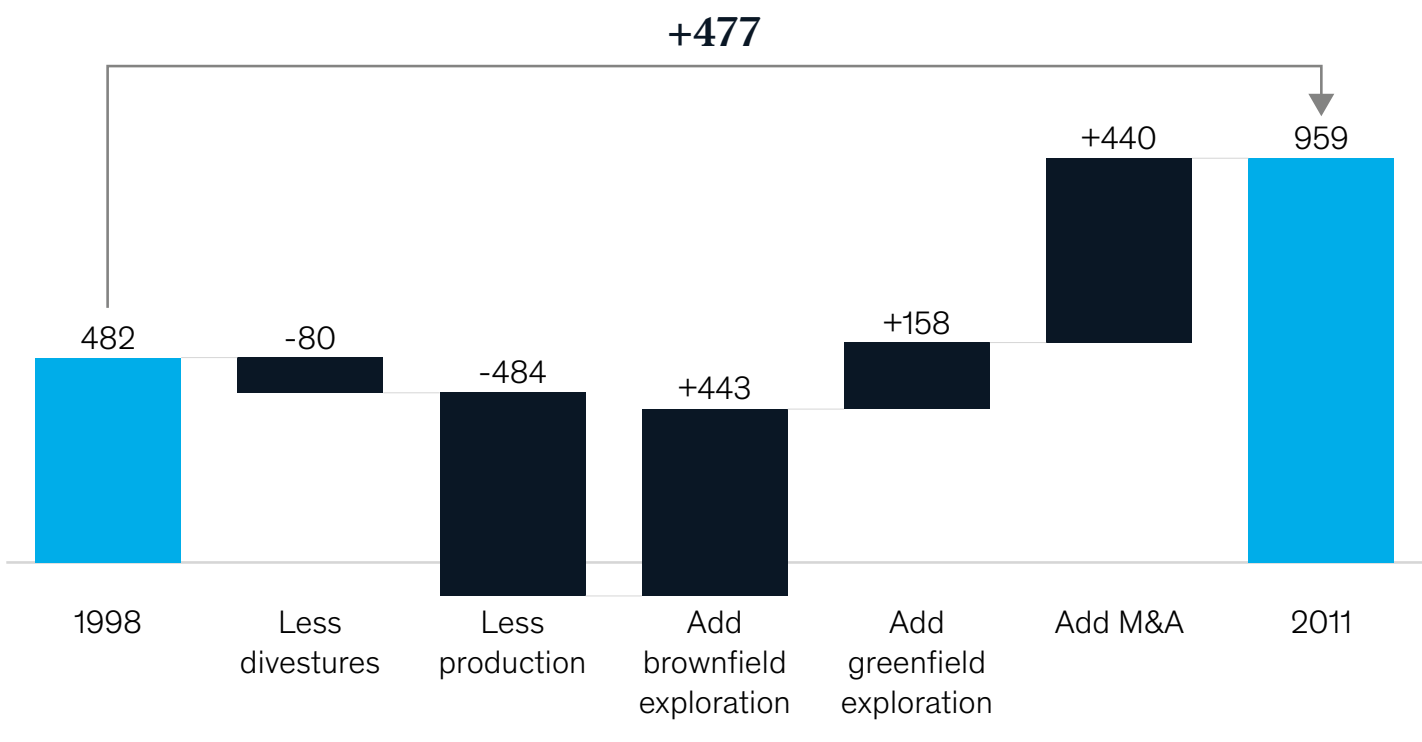

1 Agnico Eagle, AngloGold Ashanti, Barrick, China National, Freeport-McMoRan, Gold Fields, Goldcorp, Harmony, Kinross, Navoi Mining and Metallurgy Combinant, Newcrest, Newmont, Nord Gold, PJSC Polyus, Polymetal International, RandGold Resources, Shandong Gold, Sibanye-Stillwater, Yamana Gold, Zijin Mining

Source: S\&P Global Market Intelligence; company reports 
This is significant given the historical reliance large gold companies have placed on M\&A to replace and drive growth in reserves. From 1998 to 2011, M\&A represented the second largest source of reserve growth for large companies - slightly behind brownfield exploration - and correspond to 42 percent of their reserve growth over the period. Unless companies discover, build, or buy new mines, they will eventually deplete themselves out of business.

\section{The role of central banks}

Gold might be out of favor with private investors, but the world's central banks continue to buy gold bullion, with purchases concentrated in a few countries facing specific economic and geopolitical challenges - in particular China, Russia, and, more recently, Turkey. Central bank purchases bode well for long-term demand and gold's continued position as a store of value.

China's reported gold reserves have grown rapidly and currently stand at approximately 1,864 tons, up from 600 tons just a decade ago. However, Chinese supply and demand suggests that the People's Bank of China (PBOC) might be purchasing gold more often than the official numbers show. There is a belief among analysts that the PBOC has purchased well above 300 tons of gold per annum over the past few years, placing unofficial reserves marginally below 6,000 tons. Similar to China, Russia increased its gold reserves from 387 tons in 2006 to 1,890 tons in 2018, driven by US trade and financial sanctions either applied or proposed, and hence the need to hold reserve assets that are not US government debt.

There have been two key developments in 2018 that could mean central banks will want to be less reliant on the US dollar and so continue to be net buyers: first, a growing concern to reduce exposure to potential US financial sanctions; and second, the US desire to reduce its account deficit and build a stronger domestic manufacturing sector thus reducing the dollar assets able to be held outside the US as reserve assets. 


\section{The replacement imperative}

South Africa's Witwatersrand Basin is the single largest source of gold in history having produced more $150 \mathrm{BOZ}$ of gold - approximately 40 percent of the gold ever mined. After production peaked in 1970, having extracted more than 1,000 tons of gold, mining volume has steadily declined in South Africa, with the country only producing 157 tons in 2017 - an 84 percent decline. Based on known reserves and mines such as Mponeng - the world's deepest mine - estimates suggest that gold mining in South Africa may be uneconomical by 2050.

The issue of declining reserves is by no means isolated to gold mining companies on the Witwatersrand Basin: many of the world's major gold fields - for example, the United States' Carlin Trend and Australia's Super Pit - are also facing the issue of depleting reserves. Between 2012 and 2017, gold reserves of large gold companies declined 26 percent from $967 \mathrm{MOZ}$ to $713 \mathrm{MOZ}$, while the average life of mine dropped from 19 to 16.5 years. At the same time, exploration activities are yielding fewer high-grade world-scale deposits. While technology may make it possible to convert additional reserves that are currently uneconomical, we believe that there is a risk of exhausting, or nearly exhausting, reserves for many gold companies, which thus increases the strategic imperative to replenish and grow reserves. Indeed, between 2012 and 2017, only two companies - Agnico Eagle and Nord Gold - had more remaining years of production at the end of the period than at the beginning.

Exhibit 5

Reserves by major gold companies has declined 26\% since 2012 and are now below 2007 levels

Reserves by major gold companies ${ }^{1}, 2007-17$, million ounces $\mathrm{Au}$

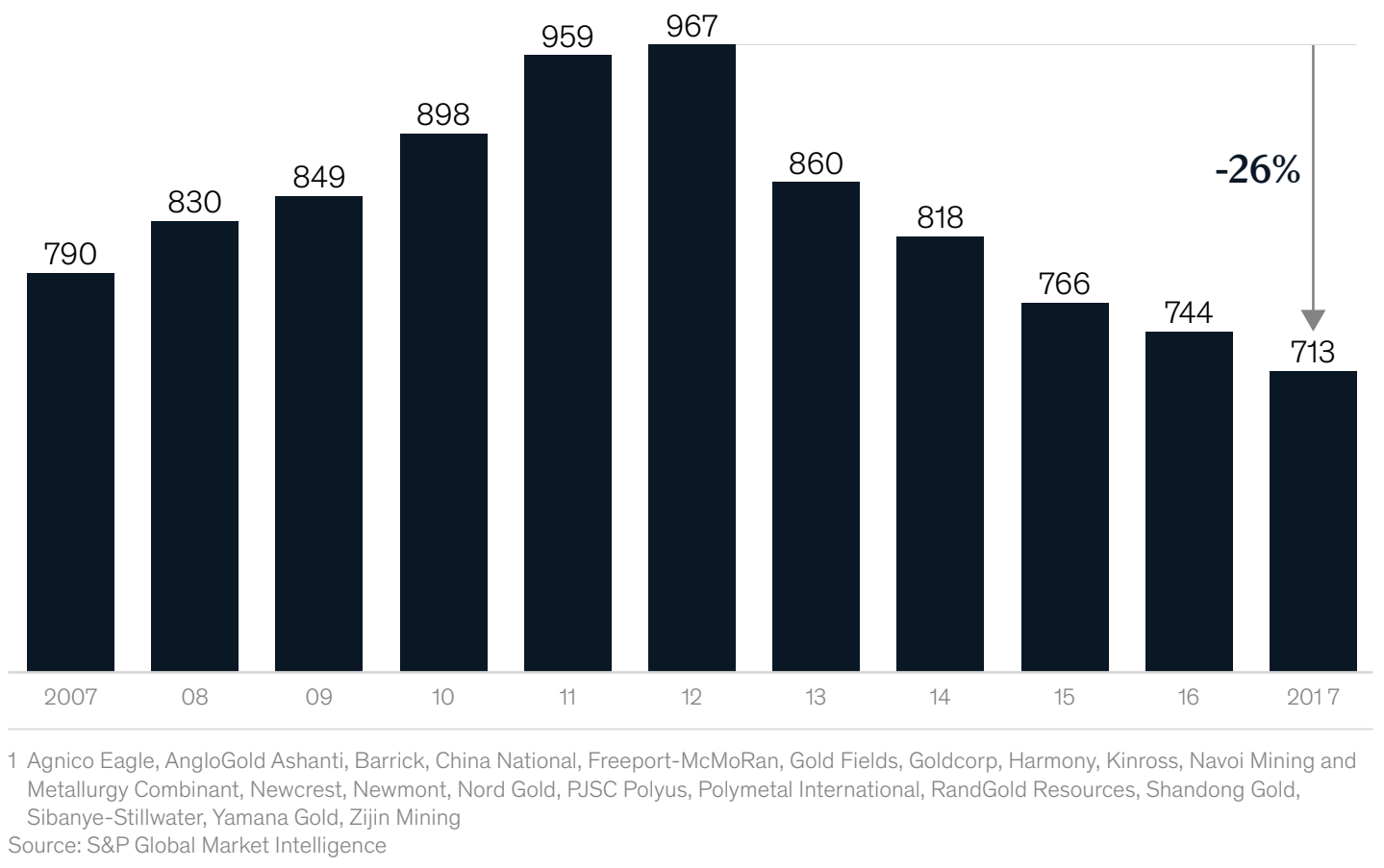




\section{Less frequent and longer to evolve}

The 1970s, 1980s, and 1990s were exciting times for gold exploration as several major gold fields were discovered, developed, and mined. During this period, the gold industry found at least one 50+ MOZ gold deposit and at least ten 30+ MOZ deposits. Since 2000, the industry has failed to find any $50 \mathrm{MOZ}$ or $30 \mathrm{MOZ}$ deposits, and very few $15 \mathrm{MOZ}$ deposits.

While the volume of gold discovered varies from year to year, in the past it has roughly followed the trend of annual spend on gold exploration with a lag effect. It is not surprising that improving industry conditions from 2003 to 2008 resulted in rapidly increasing exploration budgets and a corresponding increase in new discoveries, albeit well below the levels seen in the mid1990s. However, while budgets peaked at USD 10.5 billion in 2012, gold discoveries peaked in 2006 at approximately $206 \mathrm{MOZ}$, and since then there has been a slow decline in both the number of new discoveries and the amount of contained gold. This trend escalated in 2010 with a significant drop, and discovery rates have failed to surpass $40 \mathrm{MOZ}$ in six of the eight years since then. In the short run this may not be significant, but McKinsey's analysis suggests that it reflects a structural change with important ramifications for the gold industry.

Fewer gold discoveries. This structural change becomes clearer when looked at over a longer time period. Although gold exploration budgets have fallen dramatically since the peak in 2012, exploration spend remains at historically high levels. Over the past decade, industry spend on gold exploration has exceeded USD 50 billion, almost double the cumulative spend over the preceding two decades. However, the additional spend has not resulted in more discoveries or discovered ounces - only $216 \mathrm{MOZ}$ were found in 41 discoveries over the past

Exhibit 6

Giant discoveries have become increasing harder for junior and major gold companies in recent years

Gold discovered, 1970-2017, million ounces Au

Moderate $(0.1-1 \mathrm{Moz})$

Major (1-6 Moz)

Giant (>6 Moz)

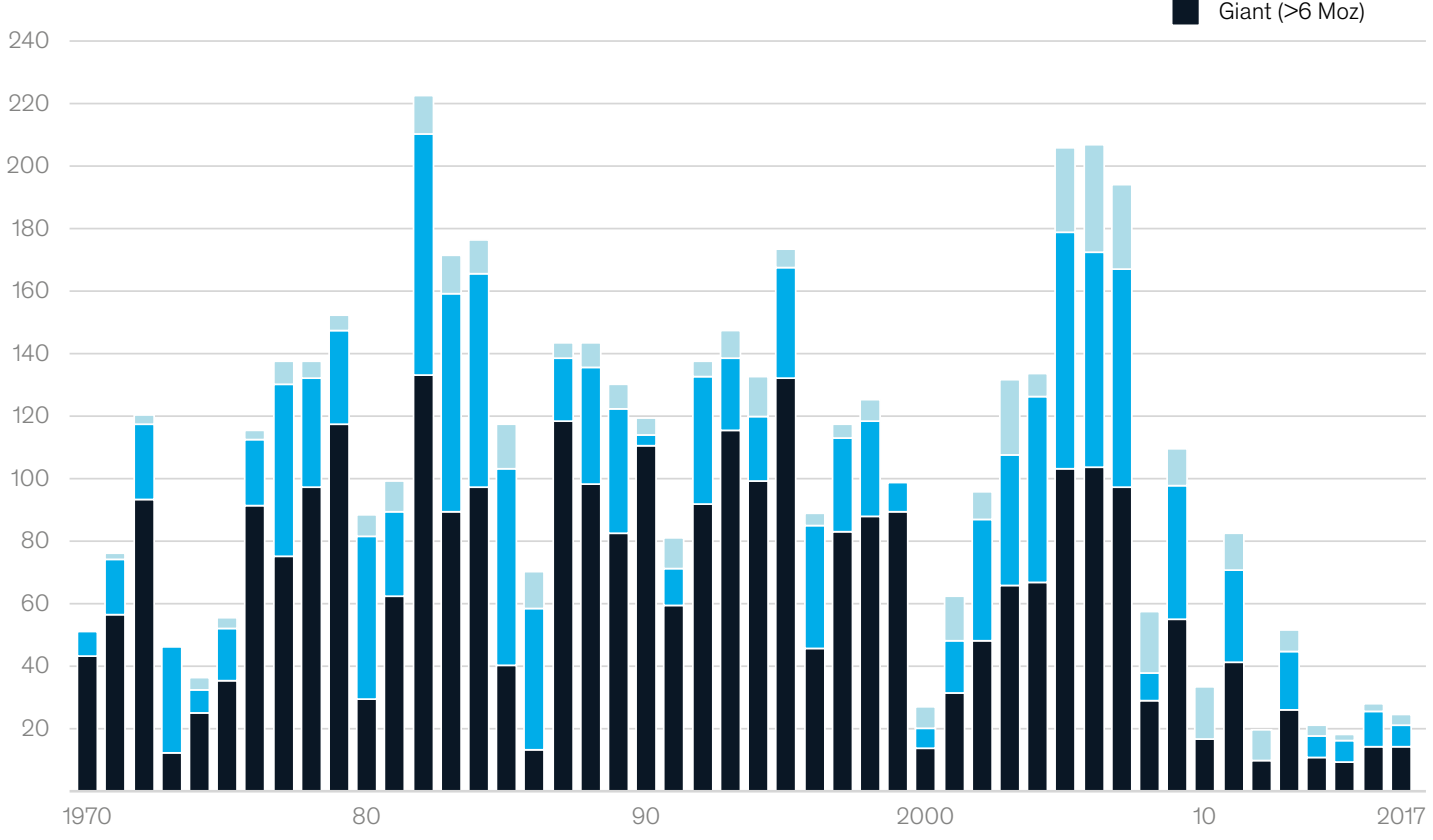


decade, compared with $1.7 \mathrm{BOZ}$ in 222 discoveries in the preceding 20 years. In the past decade, 9 of the 20 largest companies have failed to find any gold deposit large enough to be considered a major discovery, i.e., 1 Moz or above, despite spending close to USD 1 billion on greenfield exploration; for example, Kinross has spent approximately USD 265 million without a major find. It should be noted that, while the average size of discoveries is falling $-3.4 \mathrm{MOZ}$ in the last decade versus approximately $5 \mathrm{MOZ}$ in both the 1980s and the 1990s - the average grade has remained steady at approximately $1.5 \mathrm{~g} \mathrm{Au} / \mathrm{t}$.

One reason often cited for this structural change is that most of the easy-to-find deposits - or those that are in places with low geopolitical risk and hence are more attractive targets for investors - have already been discovered. From the 1980s to the early 1990s, the US, Canada, and Australia were responsible for over 40 percent of all gold deposit discoveries. In the 1990s, the focus moved over to Latin America and Africa, while in recent years, Canada has risen in importance again - today Canada accounts for approximately 30 percent of all ounces found. Industry wisdom suggests that discovering big deposits now will involve going to places like Central Africa, Central Asia, Eastern Russia, Ecuador, Mongolia, and China.

In addition, prospect discovery methods continue to be dominated by geochemistry and the extrapolation of known resources. This coincides with the depth of discovery remaining mostly 200 to 300 meters below the surface. The main exceptions in the last decade are the four $1,000+$ meter brownfield deposits discovered in Shandong Province, China. A move to deep exploration raises significant challenges for junior companies with limited funding, and very few groups are testing deep enough to discover ore bodies 1.7 kilometers below the surface.

Longer to bring into production. Even when large discoveries are made, there is evidence that it is taking longer to bring these deposits into production. The average lead time from initial targeted exploration to production for 40 major new primary gold mines that entered commercial production between 2010 and 2017 was 20 years: 10 to 13 years was spent on initial exploration work and an average of 7 years was required to progress from feasibility to commercial production. This stands in contrast to Newmont's Boddington mine in Australia and other major mines brought into production in the 1990s, where the average lead time was only 12 to 15 years. The reasons for this longer lead time include the need to raise capital to fund further work (both in times of rising and declining gold prices); increasing scrutiny from governments, local communities, and NGOs; more stringent environmental regulations; and the challenge of establishing infrastructure in increasingly remote areas. 


\section{The impact of the past seven years}

While this structural challenge has been observed and documented for some time, dramatic cost restructuring and balance sheet deleveraging since 2011 has exacerbated the situation. In 2012, the top 20 gold company reserves fell marginally short of 1,000 MOZ, after 5 years of year-on-year increases; by the end of 2017 they had declined by more than 25 percent to $713 \mathrm{MOZ}$, significantly below the level seen in 2007. We explore the reasons why the reserve situation has worsened over the past seven years below.

Funding environment dried up for juniors. In recent years, large gold mining companies have become increasingly reliant on the smaller junior gold companies to explore and replenish the gold production pipeline. In the 1980s, junior gold companies were responsible for 15 to 30 percent of all discoveries and an even smaller proportion of discovered ounces. Since 2000, junior companies have accounted for 65 to 75 percent of all discoveries and 60 to 70 percent of discovered ounces. Now, juniors have been starved of capital as investors have shunned high-risk exploration companies that traditionally rely on small public offers and private placements to fund drilling programs. Over the past five years, capital in its traditional form has dried up, with only 40 initial public offerings raising just USD 389 million. In the same time period, equity proceeds raised from follow-on equity issues by juniors have more than halved to just USD 15 billion in comparison to the four preceding years. Other funding options, such as bank debt, private placement, and royalty and streaming have had limited success. Bank debt remains difficult for juniors and typically comes with onerous conditions, given that the sector is beset with long lead times from discovery to first production and revenue. While royalty and streaming instruments have become increasingly common, with streamers executing a large number of deals with junior companies - Royal Gold has rights to over 300 assets - most of these deals are relatively small, and large funding opportunities have been targeted at late stage projects near production or brownfield expansions. For example, in 2011, Chieftain Metals entered into a streaming transaction with Royal Gold, whereby Royal Gold agreed to pay USD 60 million to advance its preliminary economic assessment study for the Tulsequah Chief Project in Canada. In return, Royal Gold received the right to purchase 12.5 percent of payable gold at USD 450/oz (decreasing to 7.5 percent at USD 500/oz after $48 \mathrm{KOZ}$ have been delivered) for the asset's life of mine.

Majors slashed exploration budgets and focused on brownfield development. Following the peak in gold prices in 2011, most majors slashed exploration budgets as companies took swift action to control costs. As a result, industry annual exploration budgets decreased from a high of USD 10.5 billion in 2012 to USD 3.2 billion in 2016. Only in 2017 did gold exploration budgets start to recover, with a 20 percent increase to USD 4 billion, but this is still more than 50 percent below peak levels. In addition, exploration budgets shifted from high-risk greenfield projects with potential to deliver new discoveries to low-risk brownfield projects whose primary function is to extend the life of mine. Between 2011 and 2017, the largest 20 gold companies spent USD 12.7 billion on exploration, with more than 75 percent allocated to late stage development and areas surrounding existing deposits. The effect of this reduced spend and limited scope meant that mining companies were barely able to replace produced ounces while converting nearby resources to reserves.

Cut-off grade revisions reclassified ore body reserves. The impact of high gold prices from 2008 to 2011 allowed companies to use lower-than-average historical cut-off grades to classify low-grade material as ore. By the end of 2012, long-term average gold prices used for reserve estimation had increased 140 percent over the previous five years and averaged approximately USD 1,400/oz - the highest being USD 1,500/oz by Barrick and Gold Fields. 


\section{Exhibit 7}

\section{Exploration budgets have shifted from high-risk greenfield projects to}

deliver new discoveries to low-risk brownfield projects

Exploration budgets by major gold companies ${ }^{1}, 2003-17$, percent, USD billions

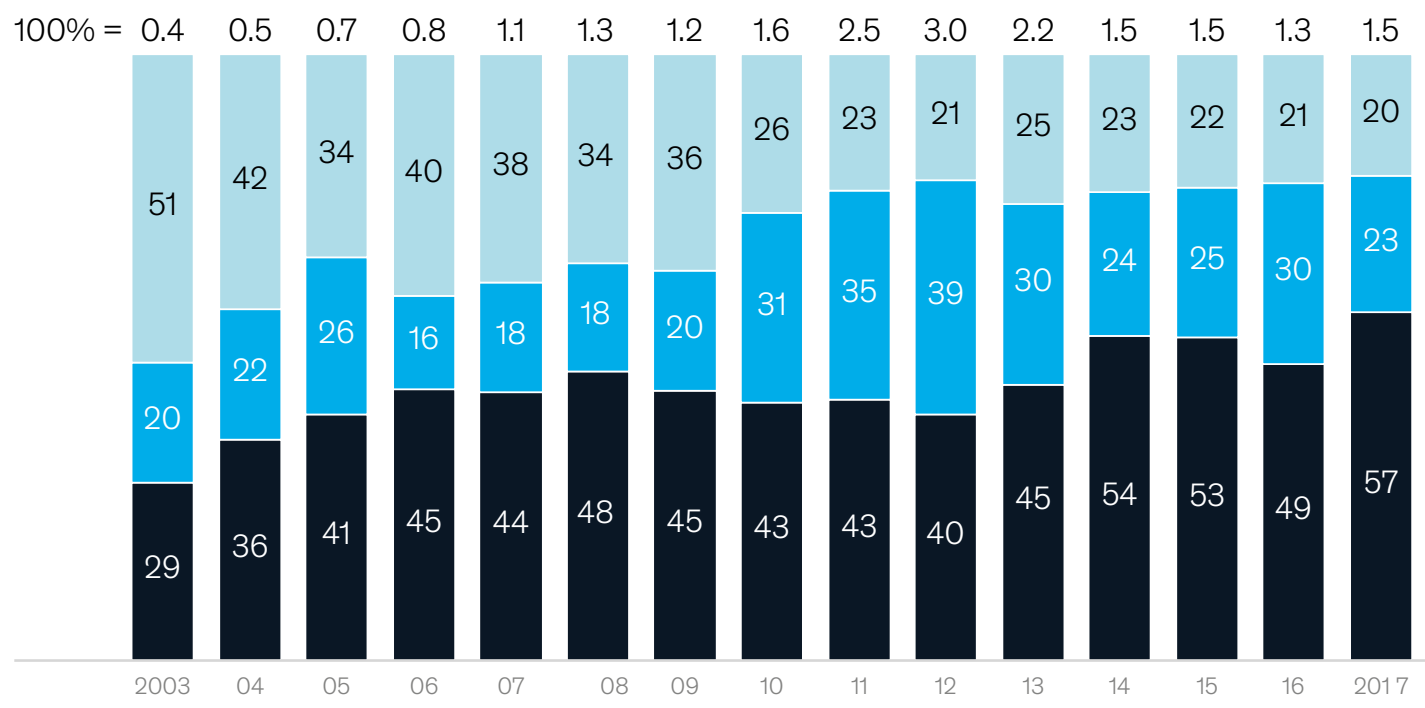

1 Agnico Eagle, AngloGold Ashanti, Barrick, China National, Freeport-McMoRan, Gold Fields, Goldcorp, Harmony, Kinross, Navoi Mining and Metallurgy Combinant, Newcrest, Newmont, Nord Gold, PJSC Polyus, Polymetal International, RandGold Resources, Shandong Gold, Sibanye-Stillwater, Yamana Gold, Zijin Mining

Source: S\&P Global Market Intelligence

After the gold price peak in 2011, the most notable change to reserves was in 2013 , when six of the eight largest gold mining companies cut long-term price assumptions. It is estimated that 20 to 50 percent of the more than $100 \mathrm{MOZ}$ taken out of reserves - an 11 percent decline in reserves - was the result of lower long-term price assumptions. Conversely, the average reserve grade improved by 8 percent as a result. Downward revisions continued in the following years, and today the same companies hold far more conservative assumptions, with many ranging between USD 1,100/oz and USD 1,200/oz.

High-grading deposits accelerated depletion. In the face of falling gold prices and cost pressure, many companies resorted to high-grading deposits - especially those companies with lower-grade and more complex ore bodies where margins are more sensitive to gold prices. In simple terms, high-grading is the mining of the highest-grade zones of an ore body to provide short-term economic benefit with the assumption that the remaining areas will be mined as gold prices improve. However, the reality is often very different, as the remaining ore body becomes only marginally economic, resulting in loss of ounces to the reserve base. High-grading probably offers gold mining companies the most efficient option to decrease costs in the short term, but for some, the long-term implication is that significant current reserves and resources will be made uneconomical. McKinsey's analysis shows that in 2016, approximately 60 percent of gold operations were mining with mill head grades above the mine's reserve grade. While mine sequencing may provide the explanation in some cases, in large part this practice was deliberately designed to increase cash flows and keep operations 
Exhibit 8
Approximately $60 \%$ of mines have been mining above their reserve grade and accelerating depletion
Mill head grade $>$ reserve grade
Mill head grade $<$ reserve grade
Mill head grade, 2016, percent
Mill head grade $=$ reserve grade

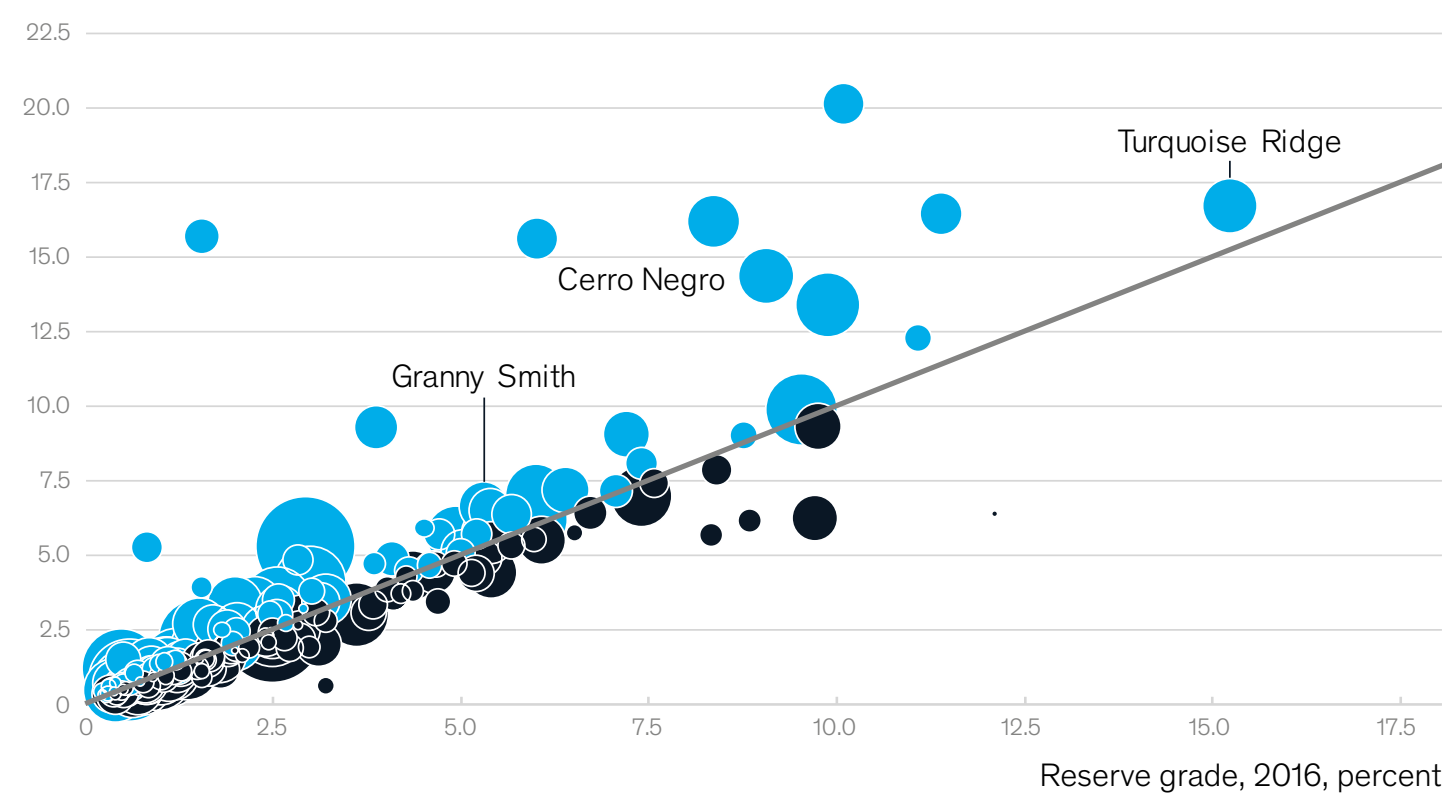

Source: MineSpans by McKinsey

in the black. Significant operations where high-grading has been observed include Granny Smith, Cerro Negro, and Turquoise Ridge. It is estimated that approximately 100 to 200 tons of additional metal was produced by the gold industry as a result of high-grading at the expense of reserves over the period between 2012 to 2016. 


\section{The role of recycling in gold supply}

The phrase "peak gold" has been used by gold CEOs and analysts in recent times to describe the looming fall in primary (mine) gold supply. While the exact date for "peak gold" is under debate, the implication is that unless the share of secondary (recycling) units increases, the result could lead to a more bullish outlook for medium- and longterm gold prices. Since gold does not tarnish or decay, all the gold ever mined still exists. Aboveground stocks today are said to be approximately $190 \mathrm{Kt}$ held in the form of jewelry (approximately 50 percent), or by private investors (approximately 20 percent), central banks (approximately 17 percent), and industrial fabricators (approximately 13 percent). While the entire aboveground stock has the potential to be recycled, only a small percentage are actually recycled each year. During the period from 2009 to 2012, when gold prices were rising and debt levels increasing, secondary supply seemed to hit a ceiling at approximately 1,750 tons per annum (surprisingly the recycling rate for gold jewelry only reached 2.1 percent of total available jewelry stock); today, with gold prices at lower levels, secondary supply ranges between 1,100 and 1,300 tons.

McKinsey's research shows that - with a weak pipeline of large projects due to become active and structural grade decline expected to continue into the long term the gold industry will require more than approximately 1,000 tons of induced supply to balance the market by 2027 . Even if jewelry recycling rates returned to the 2.1 percent level seen between 2009 and 2012, it estimated that only an additional approximate 600 tons would be added to secondary supply - insufficient to meet the approximate 1,000-ton deficit. Since such high recycling rates would not be sustainable in the long run, it is reasonable to conclude that additional primary supply - either greenfield or brownfield - will be required to meet future demand. 


\section{Implications for industry players}

The gold industry's future will depend on several factors ranging from underlying demand growth to macroeconomic variables - including interest rates, exchange rates, and inflation forecasts. What is apparent is that the industry is entering a period of growth, which in turn is raising a new challenge for mining companies to not only increase production, but also expand diminishing reserves. In the face of recent write-downs and impairments, strategies that relied primarily on acquisitions will likely be less favored and gold companies will need to improve traditional inorganic approaches as well as use new methods and technologies offered by digital and advanced analytics.

Innovations in organic exploration will provide an opportunity for companies to not only expand their reserve bases, but to also build a unique source of competitive advantage relative to their peers. This is especially the case given that the mining industry is at least a decade behind the oil and gas industry as measurement while drilling, horizontal drilling, fracturing, and 3D seismic analysis have fundamentally changed the way in which exploration is done. With lead times from discovery to first production averaging 20 years and exploration costs at historic highs, the mining industry is searching for technologies that will disrupt their current exploration business model and aid new discoveries.

Advanced analytics when applied to exploration means that companies will be able to assess a wide range of data sources, including drill logs, geological models, and unstructured map analysis simultaneously to identify new correlations and ultimately better identify mineralized zones. For example, Goldcorp has been using digital and analytics at its Red Lake operation in Canada to accelerate geological insights and achieve new levels of certainty in ore body discovery and mine planning. Different technologies will also help dramatically reduce the cost of early stage exploration; for example, the use of drones coupled with high-resolution cameras to allow tens of thousands of data points to be generated and ingested to create 3D geographical models; new high-resolution direct current (DC) resistivity surveys allowing for spacing with higher resolution compared to traditional induced polarization (IP) surveys. In British Columbia, Kinross and Agnico Eagle have co-invested in junior exploration company White Gold using these approaches in exploration activities in the Yukon White Gold district. In Australia, explorers are using biogeochemistry to understand what lies beneath the soil, while in the US hydrochemistry is being used to test groundwater that flows from mountains to valleys. These advancements will likely enable a move to undercover exploration, enabling the discovery of deeper, richer gold deposits more than 300 meters below surface, which tend to be two to four times larger in size.

Inorganic acquisition strategies will still have a role to play - as seen in the recent zero premium merger of Barrick and RandGold or the Newmont and Goldcorp merger - although the focus will need to be on rigorous, disciplined execution as management teams rebuild trust with shareholders and investors. The gold industry could take a page from the pharmaceutical $M \& A$ playbook - an industry that sees more M\&A activity than any other and similarly faces headwinds from a patent cliff with many top-selling drugs losing their patent protection in the coming years. Large pharmaceutical players have created significant value for shareholders and long-term sustainability for acquirers through megadeals that show returns 5 percent above the industry index two years after deal announcements. Simultaneously, the pharmaceutical players have pursued a series of smaller deals to access R\&D, products in the market, and entry points into emerging markets. The inorganic strategies deployed by large mining companies will need to reflect a portfolio approach balancing the near-term certainty of production growth and cash flows with longer-term growth options. This may resemble an acquisition pipeline of producing 
assets of varying scale balanced with some early and mid-stage exploration projects made through direct investments, earn-ins, or investing in exploration funds to diversify investment risk in several early stage projects. In addition, mining company strategy teams will need to look harder for sources of synergies between transactions either through focusing on specific regions, types of mineralization and ore bodies, and processing techniques that will strengthen the ability to integrate new assets into an existing production and business portfolio. Within this realm, it should be noted that divestitures will be as important as acquisitions in shaping corporate portfolios.

Technology-enabled transformations will also need to remain a priority on the agenda of management teams as the next wave of productivity is driven across the business. Having seen a massive focus on cost out and productivity initiatives over the past five years, the traditional approaches of tightly controlling capital spend, reducing expenditure on nonlabor costs, and cutting head count have likely run their course. To take advantage of future cost and productivity opportunities, gold companies will need to embrace innovations in automation machine learning, mobile digital, the Industrial Internet of Things (IloT), and blockchain. The impact will likely be seen across the value chain through, but not limited to, stochastic geological modeling, autonomous trucks and drillers, optimized mine logistics and scheduling, predictive maintenance strategies, and yield optimization at processing plants. This will assist gold companies to solve key challenges in boosting output, taking people out of mines, reducing costs and risks, and transforming uneconomical reserves into economical reserves.

The gold industry today finds itself at an inflection point between the recent era of cost out initiatives and an increasing need to focus on growth. The strategic response required will differ by company depending on various factors, including the strength of gold reserves and project pipeline, internal exploration and project development capabilities, financial balance sheet strength, and M\&A execution track record. Whatever approach is adopted, management teams will need to focus as much on organic exploration using new technologies as inorganic strategies carefully evaluated and seamlessly executed. For CEOs and management teams ready to take on the challenge, this new era could truly be a golden age.

The authors wish to acknowledge the contributions of Sigurd Mareels, Jukka Maksimainen, Michael Birshan, Ken Hoffman, James Whitecross, and Gabriel Motta in the development of this article. 

Metals and Mining Practice

February 2019

Copyright @ McKinsey \& Company

Designed by Visual Media Europe

www.mckinsey.com

y @Mckinsey

f @Mckinsey 